\title{
【特 集：容器包装リサイクル法の見直し】
}

\section{食品業界からみた容器包装リサイクル法の見直しについて}

\author{
一一経緯 と評価——
}

高 濱 正 博 *

\begin{abstract}
【要 旨】 容器包装リサイクル法の施行により, 容器包装の軽量化・薄肉化や容器包装廃裹物のリサイ クルが進展し，一般廃棄物の最終処分量の削减，最終処分場の延命などの面で効果を発揮してきた。 今回の同法の改正は, 容器包装の $3 \mathrm{R}$ の推進, 効果的なリサイクルシステムの構築を図る上で一歩前 進と評価できる。

今後とも, 現行の役割分担を維持しつつ, 各主体間の連携強化を図り, それぞれの役割を一層深化す ることが重要である。こうした観点から創設された「事業者による市町村への資金拠出制度」について は，コスト低減に向けた市町村へのインセンティブが効果的に㗢くよう運用することが求められる。

プラスチック製容器包装廃裹物については, 新たに燃料への利用（サーマル・リカバリー）を再商品 化の手法として位置づけるなど, 再商品化の合理化が緊要である。

$3 \mathrm{R}$ に向けた事業者の自主的取組（自主行動計画）の推進にあたっては，事業者の創意工夫を尊重す ることが求められる。

キーワード : 容器包装の $3 \mathrm{R}$, 役割分担，市町村への資金拠出制度，プラスチック製容器包装廃衰物の サーマル・リカバリー, 事業者の自主的取組 (自主行動計画)
\end{abstract}

\section{1.はじめに}

容器包装リサイクル法は, その附則に, 施行後 10 年 を経過した場合に見直しを行う旨の規定が設けられてい ることから, 平成 16 年夏以降, 産業構造審議会環境部 会廃棄物・リサイクル小委員会容器包装リサイクルワー キンググループ（経済産業省）と中央環境審議会廃棄 物・リサイクル部会（環境省）において, 見直しに向け た議論が続けられてきた。

さらに, 17 年 3 月からは食品容器包装のリサイクル に関する懇談会（農林水産省）においても, 議論が行わ れた。

しかし, 役割分担の変更一一具体的には, 市町村が 負担している分別収集・選別保管費用の一部を事業者が

原稿受付 2006.6. 5

* 食品産業中央協議会 常任理事

連絡先： ₹ 105-0001 東京都港区虎/門 1-16-2

E-mail : jafix-takahama@lake.ocn.ne.jp
負担すること——どの論点をめぐって, 市町村や市 民・環境団体サイドの委員と事業者サイドの委員の意見 が鋭く対立したことなどから，とりまとめは難航を極め た。

平成 18 年 1 月に至り, ようやく最終報告案が了承さ れ，これに基づいて政府において法案化の作業が進めら れ, 3 月 10 日に改正法案（正式な法律案の名称は,「容 器包装に係る分別収集及び再商品化の促進等に関する法 律の一部を改正する法律案」) が閣議決定され, 第 164 通常国会（平成 18 年 1 月 20 日開会）に提出された。

その後, 同改正法案は, 5 月の連休明けから国会での 審議が行われ, 平成 18 年 6 月 9 日に参議院本会議で可 決され, 成立した。

本稿では, 今回の容器包装リサイクル法の見直しに関 し, 審議会における論議や成立した法律の内容を中心に， 事業者——特に, 再商品化費用の過半を負担している 食品製造業一の視点から, その経緯と評価について 論じることとしたい。

周知のように, 容器包装リサイクル法は, 様々な顔を 
有する複雑な制度であることから，今回の見直しにあ たっても, その論点は,

(1) 容器包装の排出抑制 (リデュース), リターナブ ルびんなどの再使用（リュース）の推進

(2) 容器包装廃裹物のリサイクルに際しての役割（費 用）分担の見直し

(3) プラスチック製容器包装廃棄物の再商品化の合理 化（再商品化手法の見直し）

(4) ただ乗り事業者対策, 容器包装廃裹物（特に, 廃 ペットボトル）の輸出の位置づけ, 紙製容器包装 の取扱い, 指定法人のあり方, 容器包装の範囲, 小規模事業者の適用除外

など，多岐に及んだが，本稿では紙面の制約もあり， 主に(2)を中心に述べるほか，(1)および(3)について簡潔に 触れることとしたい。

\section{2. 食品の容器包装をめぐる状況}

本論に入る前に, 食品の容器包装をめぐる状況につい て，簡潔に触れておきたい。

食品の容器包装は, 内容物の品質の保持, 特に「安全 性の確保」という絶対的な要請に応え，輸送や保存を可 能とするという基本的役割を有している。このため，た とえば，マイナス 18 度以下の低温で流通する冷凍食品 の場合, その容器包装は, 耐水性, 耐油性, 遮光性に加 え，耐寒性をも考慮して材質，厚さなどが選択されてい る。加えて, 賞味期限が $1 \sim 1$ 年半にも及ぶことから, 長期的耐久性も重要視される。

これらの基本的役割に加え，消費者の視点から見た利 便性（重量，割れにくさ，扱いやすさ，ファッション性 など），容器包装のコスト（原料コストや製造コストな ど）や充填効率，表示や情報提供の面での利便性を考慮 に入れ, さらには廃衰物となった後の環境への負荷など の面にも配慮して，それぞれの商品に適した容器包装が 選択されている。

したがって, 当然のことながら, リサイクルのしやす さの観点からのみ, 容器包装が選択されているわけでは ない。

さらに, 近年, 消費者の食品の安全・安心への要求の 高まりに加え, いわゆる食の外部化の進展による調理済 み食品や加工食品への需要の増大, 食の多様化や高品質 化, 単身世帯などの増加に伴う購入単位の小型化などに より, 食品の容器包装は, 絶えざる増大圧力にさらされ ている。

環境負荷の低減, 省資源を目指した資源循環型社会の 構築を図るため, 食品についても, 容器包装の使用量を
できる限り削減し, 容器包装廃棄物の排出抑制を推進す ることは，極めて重要なことである。このため，食品業 界として屯, 過剩包装の抑制や容器包装の一層の軽量化, 薄肉化を追求しなければならないことはいうまでもない が, 消費者のライフスタイルや流通・社会構造の変革, さらには革新的な技術開発と普及が伴わない限り，そこ にはおのずから限界があることあ事実である。

\section{3. 役割（費用）分担の見直しについて}

\section{1 審議会における論議}

容器包装リサイクル法は, 一般廃㙌物に関する市町村 の処理責任を前提に，最終処分場の残余容量の逼迫への 対応と資源の有効利用の促進という観点から，一般廃棄 物の相当部分（容量で約 6 割, 重量で約 2 割）を占める 容器包装廃裹物のリサイクルを推進するため, 食品製造 業者などの事業者に再商品化義務を課したものであり, 拡大生産者責任の考え方を取り入れたものとなっている。

なお，拡大生産者責任とは，「製品が廃衰物になった 後においても，製品の生産者が一定の責任を持つべき之 の考え方（EPR）」であり，循環型社会形成推進基本法 にも規定された，わが国の廃棄物・リサイクル行政の推 進上, 重要な考え方の一つである。

容器包装リサイクル法の施行後, 消費者による分別排 出, 市町村による分別収集・選別保管，事業者による再 商品化という役割分担のもと, 容器包装廃棄物のリサイ クルは着実に進展し, 最終処理量の削減や最終処分場の 延命，資源の有効利用などの面で大きな成果をあげてき たことは，各方面から高く評価されている（表 1 および 表 2 )。

しかし, 容器包装廃棄物を含むごみの総排出量は, 大 きく減少には転じていない一方，分別収集量の増加（特 にプラスチック製容器包装廃棄物）に伴い，本制度を担 う市町村および事業者の負担感が増大していることも,

表 1 各主体の果たすべき基本的な役割

\begin{tabular}{|c|c|}
\hline 主 体 & 役 \\
\hline 消費者 & $\begin{array}{l}\text { 分別排出の徹底, 過剩包装などの製品の購入を } \\
\text { 控えるなど環境に配慮した購買行動, 納税者と } \\
\text { して市町村の廃棄物処理・リサイクル業務のあ } \\
\text { り方への関与 }\end{array}$ \\
\hline 市町村 & $\begin{array}{l}\text { 分別排出の徹底などに関し消費者への強力な動 } \\
\text { きかけ，分別収集・選別保管業務の合理化，分 } \\
\text { 別基準適合物の品質向上 }\end{array}$ \\
\hline 事業者 & $\begin{array}{l}\text { 再商品化義務の履行 (再商品化費用の支払い), } \\
\text { 容器包装の薄肉化・軽量化の推進, 発生抑 } \\
\text { 制・再使用に配慮したビジネスモデルの開発・ } \\
\text { 導入 }\end{array}$ \\
\hline
\end{tabular}


表 2 一般廃棄物の排出および処理状況なよ゙

\begin{tabular}{|l|c|c|c|}
\hline & 平成 9 年度 & 平成 12 年度 & 平成 15 年度 \\
\hline ごみ総排出量 (万 ton) & 5,120 & 5,236 & 5,161 \\
\hline 最 終 処 分 量 (万 ton) & 1,201 & 1,051 & 845 \\
\hline リサイクル率 (\%) & 11.0 & 14.3 & 16.8 \\
\hline 最終処分場の残余年数 & 11.2 & 12.2 & 13.2 \\
\hline
\end{tabular}

(出典) 環境省資料

表 3 市町村および事業者の費用負担の状況 （平成 15 年度）

\begin{tabular}{|c|c|c|c|}
\hline 区分 & 負担費用 & 負担額 & 備考 \\
\hline 市町村 & $\begin{array}{l}\text { 分別収集 - } \\
\text { 選別保管 }\end{array}$ & 3,000 億円 & $\begin{array}{l}\text { 法施行後, 新たに分別 } \\
\text { 収集を始めたことによ } \\
\text { る増加分としては， 約 } \\
380 \text { 億円 }\end{array}$ \\
\hline 事業者 & 再商品化 & 400 億円 & $\begin{array}{l}\text { 平成 } 16 \text { 年度では約 } 450 \\
\text { 億円 (うち食品製造業 } \\
247 \text { 億円 }(55 \%))\end{array}$ \\
\hline
\end{tabular}

（出典）環境省資料

否めないところである。とりわけ, 食品製造業者の再商 品化費用の負担額は大きく, 全体の再商品化費用の過半 が食品製造業の負担となっている（表 3)。

このような状況を背景に, 容器包装の $3 \mathrm{R}$ (リデュー ス、リュース、リサイクル）をさらに推進するとともに， より効率的なリサイクル・システムを実現するべく，審 議会の場において様々な議論が交わされてきたが，とり わけ，現行の役割（費用）分担を見直すかどうかをめ ぐって，延々と議論が続けられた。

この中で，分別収集・選別保管費用の增加に悩む市町 村や市民・環境団体, 学識経験者は, 拡大生産者責任を 徹底する観点からも，分別収集・選別保管費用の一部を 事業者が負担すべきであるとして，次のような主張を繰 り返した。

(1) 容器包装廃棄物のリサイクルは進展したものの, 総量としての容器包装廃棄物が減少していないの は，事業者の負担が再商品化の部分に限られてい ることに原因がある。分別収集・選別保管費用の 一部を事業者が負担すれば，その支払い額の一部 が商品価格に転嫁されることにより, 環境負荷の 大きい商品の価格が上昇し，このことが消費者に 対する環境負荷の小さい商品選択への誘引となり， 発生抑制, 再使用の進展も期待できる。

(2) 消費者は, 商品の購入後には容器包装の発生を抑 制できないことから，購入時の段階で，容器包装 の少ない商品に誘導することが必要である。この ため, 容器包装の処理費用を明示して購入の際に 消費者に対してメッセージを発することとすれば,
価格の上昇による経済的な誘引に加え，こうした 面での情報提供により，消費者の商品選択に影響 を与えることができる。

(3) 容器包装の削減については, 青果物にみられるよ うなバラ売りや消費者と小売店舗の間のリュース 容器の使用の推進など, 事業者により, あるいは 素材によっては，まだまだその余地がある。また， 事業者の支払いが増加することにより, 従前であ ればコストが高いために採用されなかった発生抑 制技術を受け入れる余地が拡大し，このような新 技術の導入によっても社会的費用を削減する途が 広がる。

(4) 容器包装の利用量は消費者により相当異なること から, 容器包装の利用量に応じた費用負担とする 方が，分別収集・選別保管費用を税金で処理する 場合に比へ，より公平性か確保される。

(5) 費用のかかる分別収集・選別保管業務を担ってい る市町村の負担に比べ，事業者の負担は軽すぎる。 分別収集に取り組めば取り組むほど市町村の費用 が増大し，市町村財政を圧迫している(いわゆる 「リサイクル貧乏」論)。

これに対し, 再商品化費用を負担している事業者は, 現行の容器包装リサイクル法は, 容器包装の軽量化, 薄 肉化や容器包装廃裹物の再商品化の推進の面で効果をあ げているとして, 現行の役割分担の堅持を訴え, 次のよ うな反論を行った。

(1) 事業者にとって現行の再商品化費用の負担は決し て軽いものではなく, 容器包装の使用削減に向け た誘引として十分機能し，既に事業者は可能な努 力をしてきている。このため, 現行以上に事業者 負担を重くしたからといって, 容器包装の削減が 進むむのではない。特に, 食品の容器包装につい ては, 内容物の安全性, 品質の保護という機能を 最優先で確保しなければならないことからこれ 以上の削減は容易ではない。

(2) 容器包装の素材選択についても，たとえば，飲料 容器の場合, 容器包装リサイクル法の施行後にお いても, 利便性が高いペットボトル入りの商品に 対する消費者の強いニーズを背景として, 再商品 化義務のない缶よりも再商品化義務のあるぺット ボトルの使用量が伸びていることにみられるよう に，事業者の負担と包装の素材選択が結びついて いない。

(3) 現在のような「買い手優位」の市場構造の下では, 商品を供給する事業者は，消費者ニーズに応えた 容器包装を付した商品を提供せざるを得ないこと 
から, 容器包装の選択に関しては, 事業者よりも 消費者の影響力が強く, 消費者の意識变革なくし て, 容器包装の削減は進まない。

(4) 消費者が商品を購入する際には，ごみ問題があま り意識されないという調查もあり, 容器包装廃棄 物についても，排出時に負担を課すことによって 消費者の意識や行動を変えることが，発生抑制に 有効である。

廃栽物収集の有料化については, 中央環境審議 会意見具申（平成 17 年 2 月）および廃棄物処理 法基本方針（平成 17 年 5 月）の中でも，一般廃 裹物の排出抑制や住民意識の改革を進める上で有 効とされ，政府の方針としても，既にその推進が 明確に謳われている。

このようなことから, 容器包装廃棄物について あ, 一般ごみと併せ, 収集の有料化を推進するこ とが必要であり，分別収集を担う市町村において は，地域の実態などを踏まえつつ，具体的な有料 化の手法や料金水準の設定, 一般ごみの混入回避 措置やチェック体制などを工夫し，その推進にあ たることが望まれる。

(5) 事業者が新たに分別収集・選別保管費用を負担す る場合は，経営内で吸収しえないコストを製品価 格に内部化し，これを最終的には消費者に転嫁す ることが必要となるが, 現在のような厳しい市場 競争の下では製品価格への転嫁は必ずしも容易で はなく，転嫁を保証するシステムを構築すること あ困難である。

(6) 仮に，製品価格に転嫁することが可能であったと してあ，転嫁される額は製品価格に比べ僅少であ ることから, 消費者の購買行動を変容させ, 消費 者の発生抑制に向けた行動を促進するほどのイン センティブにはならない。

(7) 一般廃棄物の処理は, 本来, 市町村の業務であり, 特に, 食品の容器包装廃裹物は, 生ごみと同様, 多くの家庭からほぼ毎日排出されるあのであり, 市町村の財政負担で処理をしても不都合はない。

調理済み食品や加工食品が増加する中で, 家庭 ごみにおいては調理くずなどの生ごみが減少する 一方, 食品関係の容器包装の排出量が増加してい るとみられることから, 食品関係の容器包装が生 ごみに代わって，ほとんどの家庭から日常的に排 出されているとの見方もできる。こうしたことを 考慮すれば, 食品関係の容器包装を従来どおり税 金で処理しても公平性を損なうことにならない。

８）市町村の分別収集・選別保管費用は，市町村ごと
表 4 容器包装リサイクル法の効果分析 (平成 15 年度 単位 : 億円)

\begin{tabular}{|c|r|r|c|}
\hline & 費用 & 便益 & 便益 費用 \\
\hline 事業者 & 535 & 0 & $\boldsymbol{\Delta} 535$ \\
\hline 市町村 & 1,179 & 950 & $\boldsymbol{\Delta} 229$ \\
(新規造成型) & 1,179 & 1,152 & $\boldsymbol{\Delta} 27$ \\
\hline
\end{tabular}

（注 1 ）事業者の費用は，再商品化委託費用と容器包装の使用削 減などに俰る内部コストの合計。

(注 2 ) 市町村の費用は, 収集選別費用变化分之再商品化委託費 用分の合計。便益は, 埋立処分量削減便益と可燃ごみ・ 不燃ごみ処理費用減少の合計。

（注 3 ）市町村の下欄は，直近の埋立処分場造成単価をもとにし た試算（新規造成型試算）。

（出典）「容器包装リサイクル法の勃果分析一一容器包装リサイ クル法の施行による社会的費用・便益の変化一」」(産 業構造審議会)

に数百倍から数干倍の格差があるなど，バラつき 㒂しく大きく，その業務は，効率的に行われて おらず，今後，「廃棄物会計基準」などの活用に よるコスト分析とその透明化を行うことが緊要で ある。

いずれにしても，市町村が自らの創意工夫によ りコスト削減を図ることが基本であり, 事業者に 分別収集・選別保管費用の負担を求めれば，業務 の効率化を阻害する要因となるおそれがある。

(9) 分別収集に取り組んだことによる市町村の追加的 費用は，環境省調査によれば，平成 15 年度べー スで約 380 億円であり, 同年度の事業者の再商品 化費用である約 400 億円を下回っている。また, 市町村は分別収集を行うことにより, 焼却費用や 埋立処分場の整備費用が隇少するなどのメリット ああるはずである。

一方, 事業者は, 多額の再商品化費用の負担に 加えて,「容器包装の使用削減を目的とした商品 や環境負荷の少ない容器包装の開発に要する費 用」などの内部コストを要していることも考慮に 入れる必要がある(表 4 )。

事業者側は，こうした反論を行った上で，さらに， 「消費者, 市町村および事業者のいずれにおいても，排 出抑制への取組に大きなばらつきがあり, 取組が不十分 な面が存在することは否めない。現行の役割分担の下で む, 今後さらにできることや, やるべきことが多く残さ れている状況にあり，それぞれの主体が果たすべき役割 を一層深化することが緊要である」として，現段階で役 割（費用）分担の見直し・変更を行うことは, 時期尚早 であるとの主張を行った。

\section{2 事業者による市町村への資金拠出制度の㓣設}

このような状況の中で, とりまとめに向けて, 関係者 
の間で精力的な調整が行われた結果, 市町村による分別 収集・選別保管, 事業者による再商品化という現行の役 割分担を維持した上で, 市町村と事業者がお互いの役割 を一層よく理解・認識し, 分別収集から再商品化に至る プロセスの高度化と相互の連携を強化する観点から， 「事業者による市町村への資金拠出制度」が創設される こととなった（図 1 )。

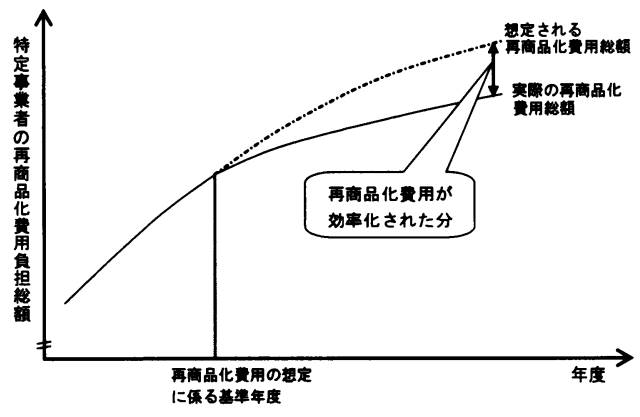

（出典）環境省資料

図 1 「事業者による市町村への資金拠出制度について (イメージ)」

同制度は，一言でいえば，効率化の成果を配分する連 携の仕組みであり, 具体的には,

(1) 市町村の取組（異物の除去, 消費者への適正な分 別排出の徹底などによる分別基準適合物の質的向 上など）と事業者の取組（容器包装の使用の合理 化, 再商品化手法の高度化など）により再商品化 費用が効率化された場合には，

(2) 当該効率化分（取組がなかった場合に想定される 再商品化費用総額と実際の再商品化費用総額の差 額）を両者で折半することとし，効率化分の $1 / 2$ を事業者から市町村へ拠出する

というあのである（なお，国会審議の中で，「平成 20 年度分として，30〜 60 億円程度の資金が事業者から市 町村に配分される」との見通しが示されている)。

今回の容器包装リサイクル法の見直しにおいて, 現行 の役割分担が維持されたことは, 事業者として評価でき るものと考えているが，上記の「事業者による市町村へ の資金拠出制度」の創設は, 現在でも多額の再商品化費
用を負担している事業者にとって厳しいものであること はいうまでもない。

また, 分別基準適合物の品質向上は, 分別収集・選別 保管を担う市町村が当然取り組むべき課題であり，この ような当然取り組むべきことに対し，事業者から資金を 拠出することについて，抵抗感を示す事業者む少なくな いと思われる。

したがって, 本制度の詳細設計や運用に際しては, 今 後,

(1) 想定される再商品化費用総額については, 過大な あのとならないよう，過去の実績などを踏まえ， 現実に即したものとするととあに，できる限り短 期間で見直す措置を講ずること

(2) 各市町村への配分については, 市町村における質 の高い分別収集・選別保管に向けた取組を効果的 に促進するインセンティブが働くよう，配分方法 を検討すること

などに配慮する必要がある。

いずれにしても, 本制度の創設により, 容器包装廃棄 物のリサイクルシステムの効率化が期待できるむのと考 えているが，その細目については，今後の調整に委ねら れており，その行方が注目されるところである。

なお, 本制度は, 平成 20 年 4 月から施行されること から，はじめて拠出金が市町村に支払われるのは, 平成 20 年度の再商品化費用総額の効率化分が明らかとなる 平成 21 年夏ごろと予想される。

\section{4. プラスチック製容器包装廃棄物の再商品化 の合理化}

プラスチック製容器包装廃裹物の再商品化費用は, 近 年, 急増しており, リサイクルの始まった平成 12 年度 には 65 億円であったものが, 16 年度には 352 億円にも 達し, 再商品化費用総額 451 億円の 8 割近くを占めるに 至っている（表 5 )。

このまま推移すれば, プラスチック製容器包装廃棄物 の再商品化費用は, 平成 22 年度には 860 億円に達する

表 5 再商品化費用（事業者負担分）の推移（単位：億円）

\begin{tabular}{|c|c|c|r|r|r|r|}
\hline & 9 年度 & 12 年度 & 13 年度 & 14 年度 & 15 年度 & 16 年度 \\
\hline 合 計 & 14 & 164 & 269 & 334 & 399 & 451 \\
\hline 紙 & - & 12 & 12 & 9 & 9 & 8 \\
\hline プラスチック & - & 65 & 145 & 215 & 290 & 352 \\
\hline ペットボトル & 9 & 69 & 91 & 91 & 84 & 75 \\
\hline ガラスびん & 6 & 19 & 22 & 19 & 15 & 16 \\
\hline
\end{tabular}

(出典) (盺)日本容器包装リサイクル協会資料 
との予想も示されている。

このように再商品化費用が急增しているのは, 新たに 分別収集に取り組む市町村が増加し, 分別収集量が急増 していることに加え, 再商品化能力に余裕がそしくなっ ていることや再商品化単価の高い材料リサイクル（プラ スチックの原料にリサイクルする手法で，マテリアルリ サイクルとあいう）を優先していることなどから，再商 品化単価が高止まりしていることに原因がある。

このようなことから, 今般, プラスチック製容器包装 廃裹物の再商品化の合理化を推進するため, 次のような 措置を検討することとされた。

(1) 市町村は, 食品の残椬などで污れたものについて は, 分別収集の対象から除外し，一般ごみとして 処理することを徹底する（これにより，当然のこ とながら, 再商品化の対象外となるととあに, 分 別収集基準適合物の品質が向上し, 再商品化費用 単価の低下も期待される)。また, 異物の混入し た廃棄物の収集の見合わせなどにより，分別排出 の徹底に関し住民に強力に働きかける。

一方, 指定法人（財) 日本容器包装リサイクル 協会）は，基準を満たさない分別基準適合物につ いては，市町村からの引取りを拒否する。

(2) 再商品化費用の商正化の観点から, 再商品化事業 者を決定するための入札の方法について，標準コ ストを基礎とした方法の導入などを行う。

(3) 再商品化の質の向上を図るため, 消費者にわかり やすい材質表示を容器包装に付するなどの措置を 図った上で，プラスチック製容器包装の分別収集 をよりきめ細かなものとする。このため，たとえ ば, マテリアルリサイクルに適した特定の容器包 装（材質がポリエチレンやポリプロピレン単体で あり，形状により容易に判別できるむのなど）に ついて, 他と異なる識別表示を付し, 他のプラス チック製容器包装と区分して分別収集する。

(4) 分別収集量が再商品化の能力を上回った場合など における補完的または緊急避難的な手法として, 現在は再商品化の手法として認められていない燃 料への利用（いわゆるサーマル・リカバリー）を 認めることとし, 市町村の一般廃棄物処理施設に おける発電・熱利用と比較して, 高い効率を満た し優位な利用が可能である場合などには，再商品 化の手法として制度上位置づける。

これらの措置は，いずれも，プラスチック製容器包装 廃棄物の再商品化の合理化を図る上で, 検討に值するあ のであるが, この中で, サーマル・リカバリーの導入に ついては, 分別収集量が再商品化能力を上回る場合など
の補完的または緊急避難的な対応に限定することなく， マテリアルリサイクルやケミカルリサイクルと並ぶ, 恒 常的な手法として明確に位置づけるべきであると考える。 当面, サーマル・リカバリーの対象としては, RPF (固形燃料化)やセメント原燃料などが考えられるが, 今後, さらに, 技術革新の進展を踏まえ, ライフ・サイ クル・アセスメントなどの手法を活用しつつ, 環境負荷, 経済性を考慮した上で, 新たな対象を検討すべきであろ う。

\section{5. 容器包装の $3 \mathrm{R}$ に向けた事業者による自主 的取組の促進}

容器包装廃棄物の排出抑制の推進は, 循環型社会を形 成する上で最む基本となることであるが，その取組には， 事業者間で依然として大きなばらつきがあり, 今後, 容 器包装の $3 \mathrm{R}$ に向けた自主行動計画の策定を通じて, 取 組の遅れている事業者の底上げを図ることが緊要である。

しかし,こうした自主的取組の推進にあたっては, 容 器包装の種類や使用目的は多様であり, 個々の業種・製 品の実態や食品の安全の確保などの他の達成すべき目的 とのバランスも考虑する必要があることから, 事業者の 創意工夫を尊重し, 取組における柔軟性を確保すること が重要であると考える。

したがって, 取組の遅れている事業者の底上げを図る との事由で, 行政が過剩に介入し, 法令による画一的な 規制を行うことはできる限り避けることが望ましい。

今回の改正法においては, 小売業のレジ袋の削減を念 頭において，事業者の自主的な取組を促進するため, 排 出抑制に係る指針（事業者の判断の基準となるべき事 項）の策定, 事業者による達成状況の報告, さらには取 組が著しく不十分な, 多量の容器包装を利用する事業者 への勧告, 命令などの措置を講ずることとされたところ である。

レジ袋は， 1 年間に約 300 億枚（平均して，1 1 1日 1 枚）使用され，家庭ごみに占める割合も高い（家庭か ら出るプラスチックごみに占める割合は, 重量, 容積比 とも約 15\%）一方, 小売店の販売形態の工夫や消費者 意識・行動の変容 (マイバッグの持参) を通じて, 削減 しうる余地の大きいあのであり, 今後, 事業者による取 組と国民の意識の向上があいまって，レジ袋の削減が進 展することを期待したい。

なお，審議会では，レジ袋の有料化を法律で義務づけ ることも話題となったが, 無料提供を一律に法律で禁止 することは，過度の経済的規制になりかねず，憲法で保 障されている「営業の自由」を侵すほか, 実効性を担保 
することも困難であることから，見送られることとなっ た。

\section{6. お りに}

今回の容器包装リサイクル法の見直しは, 総じてみれ ば, 同制度の効果的・効率的な運用を図る上で, 一歩前 進と評価できるあのであり, 容器包装の $3 \mathrm{R}$ に向け, 各 主体が連携を強化しつつ, それぞれの取組を深化するこ とに奇与するものと考えられる。

食品事業者としても, 容器包装に係るリサイクル八団 体（ガラスびん, ペットボトル, 紙製容器包装, プラス チック容器包装, スチール缶, アルミ缶, 飲料用紙容器 および段ボールの素材別リサイクル推進団体）が平成 18 年 3 月 28 日に公表した「容器包装の $3 \mathrm{R}$ 推進のため の自主行動計画」を視野に入れつつ，3Rに向けた取組 を強化する必要があると考えている。

その一環として, 今後, 容器包装製造事業者や食品以 外の容器包装利用事業者, リサイクル事業者, さらには 消費者, 市町村, 関係省庁, 大学などの試験研究機関な どの幅広い関係者との連携の下, 将来を見通した様々な モデル事業の実施や改正法の効果検証にも積極的に参加 していきたいと考えている。

いずれにしても, 容器包装リサイクル制度が一層, 効
率的で持続的なものへと転換し，従来にも増して環境負 荷の低減や資源の有効利用に寄与し, 循環型社会の構築 に貢献することを期待したい。

\section{茭考文献}

・中央環境審議会 : 今後の容器包装リサイクル制度の在り方 について (意見具申)（2006）

・産業構造蕃議会環境部会廃衰物・リサイクル小委員会容器 包装リサイクルワーキンググループ: 容器包装リサイクル 法の評価検討に関する報告書一一持続可能な省資源社会 を目指して一 (2006)

・食品容器包装のリサイクルに関する想談会 : 食品容器包装 の $3 \mathrm{R}$ の促進に向けて〜循環型社会の実現を目指して〜 (食品の容器包装リサイクル制度の見直しに係る検討結果 とりまとめ) (2006)

- 高濱正博：容器包装リサイクル法の見直しについて, (盺)食品産業センター, 明日の食品産業, 3月号 pp. 3-11 (2006 年)

- 高濱正博 : 容器包装リサイクル法の見直しと食品業界, (㽗) 食品産業セン夕ー, 明日の食品産業, 4 月号, pp. 1015 (2006)

・ (社) 日本経済団体連合会: 実勃ある容器包装リサイクル制 度の構築について (2005)

・容器包装に係るリサイクル八団体：「容器包装の $3 \mathrm{R}$ 推進 のための自主行動計画等の策定」と「 $3 \mathrm{R}$ 推進団体連絡会 の結成」(2006) 


\title{
Food Industry View on the Revised Law for the Promotion of Sorted Collection and Recycling of Containers and Packaging: Process and Evaluation
}

\author{
Masahiro Takahama \\ Executive Director, Society of Japan Food Industry \\ ( 1-16-2 Toranomon, Minatoku, Tokyo, 105-0001 Japan)
}

\begin{abstract}
Enforcement of this Law has often taken the form of promoting that containers and packaging should always be made lighter and thinner in order to both work toward a reduction in the volume of waste, and to better maintain equipment for disposing so that it lasts longer. The Law's most recent revision is expected to have the following effects: a) Promotion of the 3Rs : Reduce, Reuse, Recycle ; and b) Establishment of an effective recycling system.

While maintaining the original role allocations, it will also be necessary to reinforce good communication among all the players and firm up the role of each player within the scheme of the Law. New funds, created in this context for the municipal governments, could be raised and donated by business players to effectively reduce costs.

It is strongly advised that a study should be conducted on how waste from containers and packaging made of plastics could be used as a recyclable source of new energy (thermal recovery) on a commercial basis. Also, original efforts by business players must be respected in order to promote voluntary actions toward the 3Rs.

' Law of Promotion of Sorted Collection and Recycling of Containers and Packaging; June 16, 1996, Law No. 112

Key words : 3 Rs on containers and packaging, role-allocation, municipal government funding by business players, thermal recovery using waste from plastic containers and packaging as a recyclable source of new energy, voluntary actions (3R programs conducted by businesses)
\end{abstract}

